Jurnal Ekonomi dan Industri

e-ISSN: $2656-3169$

Volume 22, No.3, September-Desember 2021

p- ISSN: 0853-5248

\title{
PENGARUH KOMUNIKASI, LINGKUNGAN KERJA DAN BEBAN KERJA TERHADAP KEPUASAN KERJA KARYAWAN PT. KREASICIPTA AKSESDASISINDO JAKARTA
}

\author{
Nona Aprillina 1) \\ 1) Fakultas Ekonomi Universitas Darma Persada \\ Ismail Razak 2) \\ 2) Dosen Program Studi Manajemen FE Unkris \\ Alamat: Kampus UNKRIS, Jatiwaringin Jakarta Timur \\ Email: ismailrazak.zain@gmail.com
}

\begin{abstract}
The purpose of this study was to analize the effect of communication, job environment, and job load on job satisfaction of the PT. Kreasicipta Aksesdasisindo, Jakarta. Primary data was obtained from employee of the PT. Kreasicipta Aksesdasisindo, Jakarta through admission filling of questionnaire by using scale of Likert. Data analysis technique used in this research is simple linear regression and multiple linear regression. The results of this study indicated that communication, job environment, and job load positively and significant influenced the job satisfaction of the PT. Kreasicipta Aksesdasisindo, Jakarta.
\end{abstract}

Keywords: Communication, job environment, job load, and job satisfaction

\section{PENDAHULUAN}

Suryaningsih menyatakan bahwa faktor-faktor yang mempengaruhi kepuasan kerja karyawan memiliki tingkat yang berbeda-beda sesuai dengan nilai yang berlaku pada dirinya (Putra dan Adnyani, 2019). Komunikasi sangat penting dan merupakan kunci pembuka dalam meningkatkan kepuasan kerja karyawan. Menurut Wulandari, et al (2018), komunikasi sangat penting untuk menjalin hubungan kerja sama antara manusia yang terlibat dalam perusahaan dan mempunyai pengaruh sangat besar dalam proses pencapaian tujuan perusahaan. Peranan komunikasi dalam meningkatkan kepuasan kerja karyawan sangat penting karena sistem komunikasi yang baik akan memberikan kepuasan kerja karyawan dan meningkatkan produktivitas karyawan. Dengan komunikasi seseorang dapat menyampaikan keinginan yang terpendam dalam hatinya kepada orang lain, baik melalui suara, bahasa tubuh, atau isyarat dan sebagainya. Semakin lancar dan cepat komunikasi yang dilakukan, akan semakin cepat pula terjalinnya hubungan kerja.

Menurut Aoliso dan Lao (2018), lingkungan kerja perusahaan merupakan suatu faktor yang mendukung terciptanya kepuasan kerja karyawan. Kondisi kerja yang baik akan sangat besar pengaruhnya dalam meningkatkan kepuasan kerja karyawan, karena lingkungan kerja yang baik berperan penting dalam mengurangi suasana lelah serta dapat menghilangkan atau paling sedikit mengurangi rasa jenuh. Sebaliknya lingkungan kerja yang buruk akan mempengaruhi pekerjaan menjadi menurun, karena karyawan merasa terganggu dalam pekerjaan. Menurut Hurley et al, lingkungan kerja memiliki kontribusi yang signifikan bagi kepuasan kerja karyawan, sehingga lingkungan kerja karyawan memiliki efek yang kuat terhadap kepuasan kerja (Prassetiawan dan Triyani, 2018). 
Mustapha membuktikan bahwa beban kerja berpengaruh terhadap kepuasan kerja, artinya karyawan lebih puas terhadap pekerjaan ketika beban kerja yang mereka dapatkan lebih rendah (Wahyuni dan Irfani, 2019), sedangkan menurut Novita dan Kusuma (2020) beban kerja yang sedikit tentunya akan menimbulkan kepuasan dalam diri karyawan. Beban kerja dapat dilihat dari beban kerja fisik maupun mental. Apabila beban kerja yang ditanggung seorang karyawan terlalu berat atau kemampuan fisik yang lemah tentu akan mengakibatkan suatu hambatan dalam bekerja sehingga karyawan tersebut akan merasa sakit.

Hasil penelitian ini merupakan pengembangan hasil penelitian yang dilakukan oleh Wuwung, et al (2017), Aolio (2018), Prassetiawan (2018), Wulandari, et al (2018), Yunsepa (2018), Diana (2019), Putra dan Adnyani (2019), Fachrezy (2020), dan Novtia (2020) mengenai sumber daya manusia yang menjelaskan hubungan kausalitas antara komunikasi, lingkungan kerja dan beban kerja dengan kepuasan kerja.

PT. Kreasicipta Aksesdasisindo merupakan salah satu bentuk perusahaan yang bergerak di bidang jasa infrastruktur jaringan, jasa pemeliharaan dan juga penjualan produk untuk cable system, perangkat IT support dan lainnya. Dibentuk untuk memenuhi kebutuhan sistem jaringan dan juga berfokus penyediaan sistem kabel terstruktur dan infrastuktur jaringan di Indonesia.

Berdasarkan data observasi dengan menyebarkan kuesioner terhadap 20 karyawan tentang komunikasi, lingkungan kerja, dan beban kerja, terhadap kepuasan kerja karyawan PT. Kreasicipta Aksesdasisindo. Berikut adalah diagram yang menunjukkan penerapan komunikasi, lingkungan kerja, dan beban kerja, terhadap kepuasan kerja karyawan PT. Kreasicipta Aksesdasisindo dapat dilihat dalam Gambar-1.

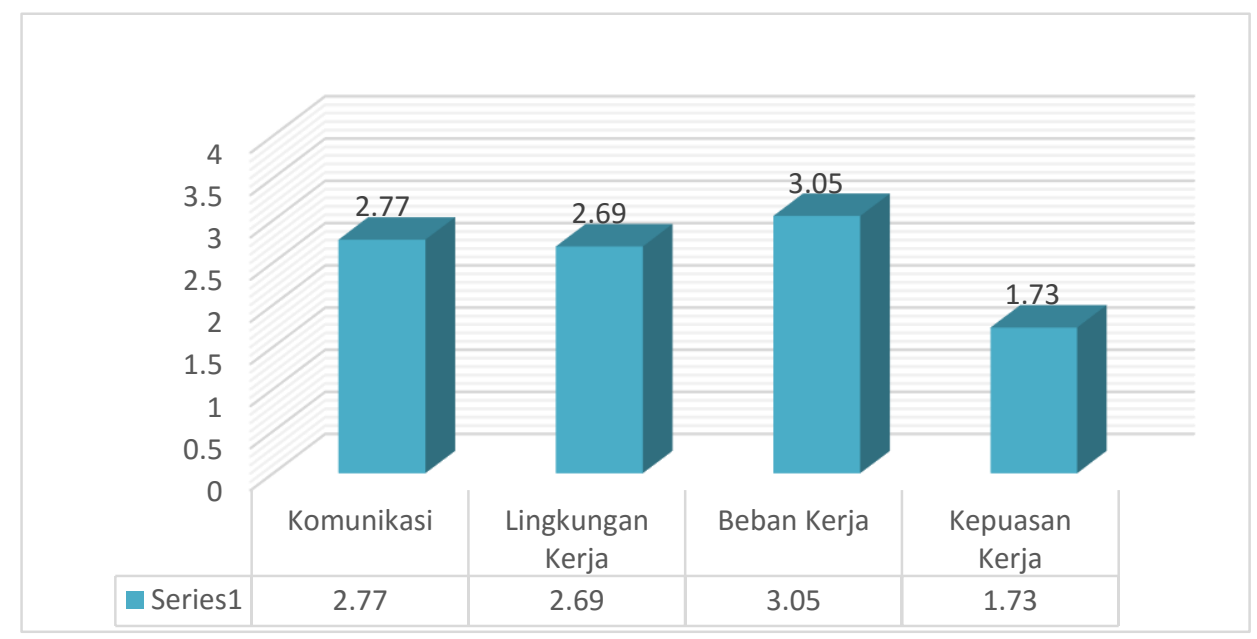

Sumber: Data primer, diolah, 2021

\section{Gambar 1: Grafik Tanggapan Responden}

Berdasarkan grafik dalam Gambar-1 dapat diperoleh hasil tanggapan responden komunikasi, lingkungan kerja, dan beban kerja terhadap kepuasan kerja dengan rata-rata sebagai berikut, komunikasi sebesar 2,77 yang berarti penerapan komunikasi yaitu cukup baik, tanggapan responden untuk lingkungan kerja sebesar 2,69 menunjukkan penerapan lingkungan kerja yaitu cukup baik, dan tanggapan responden untuk beban kerja sebesar 3,05 menunjukkan beban kerja yang tinggi, kemudian tanggapan responden untuk kepuasan kerja 
karyawan sebesar 1,73 artinya responden menyetujui bahwa kepuasan kerja karyawan di PT. Kreasicipta Aksesdasisindo sangat rendah.

\section{LANDASAN TEORI}

\section{Komunikasi}

Menurut Syamsudin dan Firmansyah (2016), komunikasi organisasi merupakan struktur dan fungsi organisasi, hubungan antar manusia, komunikasi dan proses pengorganisasian serta budaya organisasi, sedangkan menurut Handoko, komunikasi adalah proses perpindahan pengertian dalam bentuk gagasan atau informasi dari seseorang ke orang lain, yang melibatkan lebih dari sekedar kata-kata yang digunakan dalam percakapan, tetapi juga ekspektasi wajah, intonasi, titik fokus lokal, dan sebagainya (Ngalimun, 2017). Menurut Ruliana (2016) komunikasi mengacu pada tindakan satu orang atau lebih yang mengirim dan menerima pesan, terjadi dalam suatu konteks tertentu, mempunyai pengaruh tertentu, dan ada kesempatan untuk melakukan umpan balik (feedback) yang dipengaruhi oleh lingkungan (konteks) dimana komunikasi itu terjadi.

Berdasarkan pengertian tersebut dapat disimpulkan bahwa komunikasi adalah penyampaian informasi dari satu pihak ke pihak yang lain, baik sadar maupun tidak sadar. Untuk melakukan komunikasi yang baik perlu mengetahui situasi serta kondisi serta karakteristik lawan bicara, antar individu dalam suatu lingkungan.

Indikator komunikasi menurut Purwanto (2015) adalah indikator vertikal, indikator horizontal, dan indikator diagonal. Indikator vertikal terdiri atas 1) Komunikasi yang berasal dari atas ke bawah, yaitu perintah, prosedur, teguran dan pujian, dan 2) Komunikasi yang berasal dari bawah ke atas, yaitu saran dan laporan pekerjaan. Indikator horizontal, yaitu informasi, koordinasi tugas dengan bagian yangsama dan rapat. Indikator diagonal, yaitu informasi diterima dengan cepat, hubungan antar divisi dan koordinasi dengan bagian lain.

\section{Lingkungan kerja}

Menurut Mangkunegara (2017) lingkungan kerja merupakan keseluruhan alat perkakas dan bahan yang dihadapi, lingkungan sekitarnya dimana seseorang bekerja, metode kerjanya serta pengaturan kerjanya baik sebagai perseorangan maupun kelompok, sedangkan menurut Efendi (2018), lingkungan kerja adalah segala sesuatu yang ada di sekitar para pekerja atau karyawan yang dapat mempengaruhi kepuasan kerja karyawan dalam melaksanakan pekerjaannya. Menurut Robbins, lingkungan kerja adalah suatu kondisi dimana didalamnya para karyawan melaksanakan suatu aktivitas (Dino, 2019).

Berdasarkan pengertian tersebut dapat disimpulkan bahwa lingkungan kerja merupakan suatu sarana atau keadaan yang dapat untuk mengoptimalkan kualitas serta kinerja para karyawan yang berada di perusahaan. Dalam lingkungan kerja tersebut terdapat fasilitas kerja yang mendukung karyawan dalam penyelesaian tugas yang di bebankan kepada karyawan guna meningkatkan kerja karyawan dalam suatu perusahaan. Kondisi tersebut bisa berupa material maupun kondisi psikologis yang dalam hal ini lingkungan kerja berhubungan dengan fisik, sehingga manusia dengan keterampilan yang ada harus mampu memanfaatkan setiap sarana yang ada secara optimal.

Menurut Sedarmayanti (2016), indikator lingkungan kerja dapat diukur melalui lingkungan fisik dan lingkungan non fisik. Lingkungan fisik adalah lingkungan sekitar 
pekerja, seperti penerangan, suhu udara, suara bising, penggunaan warna, dan keamanan kerja. Lingkungan non fisik adalah hal-hal yang berkaitan dengan hubungan sosial dan organisasi, seperti hubungan kerja antara pimpinan dan bawahan, dan hubungan kerja antara rekan kerja.

\section{Beban kerja}

Menurut Mudayana, beban kerja merupakan sesuatu yang muncul dari interaksi antara tuntutan tugas-tugas (Hannani, et al, 2016), sedangkan menurut Tarwaka, beban kerja merupakan pekerjaan yang dilakukan dengan uraian tugas yang seharusnya diselesaikan pada batas waktu tertentu (Wahyuni dan Irfani,2019). Menurut Asianto dan Suprihadi, beban kerja adalah sebagai suatu perbedaan antara kapasitas atau kemampuan pekerja dengan tuntutan pekerjaan yang harus dihadapi (Diana, 2019).

Bedasarkan pengertian tersebut dapat ditarik kesimpulan bahwa beban kerja merupakan pekerjaan yang diberikan atasan kepada karyawan yang diluar batas kemampuan karyawan tersebut, sehingga karyawan tersebut tidak dapat mengerjakan pekerjaan yang telah diberikan kepadanya.

Menurut Koesomowidjojo (2017), terdapat beberapa indikator yang mampu mengetahui besarnya beban kerja pada suatu perusahaan yang harus diterima oleh karyawan, yaitu sebagai berikut; 1) Kondisi pekerjaan; Kondisi pekerjaan yang dimaksud adalah bagaimana seorang karyawan memahami pekerjaan tersebut dengan baik.

Penggunaan waktu kerja; Penggunaan waktu kerja yang sesuai dengan prosedur operasi standar dapat meminimalisir beban kerja karyawan. 3) Target kerja yang harus dicapai; Target kerja yang harus dicapai merupakan kinerja optimal seorang karyawan.

\section{Kepuasan Kerja}

Menurut Rivai (2015), kepuasan kerja adalah evaluasi yang menggambarkan seseorang atas perasaan sikapnya senang atau tidak senang, puas atau tidak puas dalam bekerja, sedangkan menurut Robbins, kepuasan kerja sebagai sikap umum terhadap pekerjaan seseorang, yang menunjukkan antara jumlah penghargaan yang diterima pekerja dan jumlah yang diyakini oleh pekerja yang seharusnya diterima (Hamali, 2016). Menurut Jex, kepuasan kerja sebagai tingkatan efeksi positif seorang pekerja terhadap pekerjaan dalam situasi pekerjaan, kepuasan kerja berkaitan dengan sikap pekerja atas pekerjaannya (Sinambela, 2018).

Berdasarkan pengertian tersebut dapat disimpulkan bahwa kepuasan kerja adalah evaluasi yang menggambarkan bagaimana respon karyawan terhadap apa yang karyawan terima dari perusahaan, disebabkan karyawan telah melakukan pekerjaan. Pada hakikatnya kepuasan kerja merupakan tingkat perasaan senang seseorang terhadap penilaian positif terhadap pekerjaannya dan lingkungan tempat kerjanya.

Robbins dalam Sinambela (2018) menyatakan bahwa ada empat indikator kepuasan kerja, diuraikan sebagai berikut; 1) Pekerjaan yang menantang secara mental; Karyawan cenderung memiliki pekerjaan yang memberikan kesempatan menggunakan keahlian dan kemampaaun, serta menawarkan variasi tugas, kebebasan, dan umpan balik seputar sebaik mana pekerjaan yang mereka lakukan. 2) Penghargaab yang memadai; Kecenderungan pekerja dalam menginginkan sistem penghasilan dan kebijakan promosi yang diyakini adil, tidak mendua, dan sejalan dengan harapannya. 3) Kondisi kerja yang mendukung; Perhatian pekerja pada lingkungan kerja, baik kenyamanan ataupun fasilitas yang memungkinkan 
mereka melakukan pekerjaan secara baik. 4) Kolega yang mendukung; Karyawan selain bekerja juga mencari kehidupan sosial. Tidak mengejutkan bahwa dukungan rekan kerja mampu meningkatkan kepuasan kerja seorang pekerja.

\section{Hipotesis}

Hipotesis dalam penelitian ini adalah 1) Komunikasi berpengaruh positif dan signifikan terhadap kepuasan kerja karyawan PT. Kreasicipta Aksesdasisido, Jakarta, 2) Lingkungan kerja berpengaruh positif dan signifikan terhadap kepuasan kerja karyawan PT. Kreasicipta Aksesdasisido, Jakarta, 3) Beban kerja berpengaruh positif dan signifikan terhadap kepuasan kerja karyawan PT. Kreasicipta Aksesdasisido, Jakarta, dan 4) Komunikasi, lingkungan kerja, dan beban kerja berpengaruh positif dan signifikan terhadap kepuasan kerja karyawan PT. Kreasicipta Aksesdasisido, Jakarta,

\section{METODE PENELITIAN}

\section{Metode Pengumpulan Data}

Sumber data yang digunakan dalam penelitian ini adalah data primer, yaitu data yang diperoleh langsung melalui penyebaran kuesioner dengan menggunakan skala Likert kepada karyawan PT. Kreasicipta Aksesdasisido, Jakarta sebagai responden. Skala Likert yang digunakan terdiri atas; sangat setuju dengan bobot 4 , setuju dengan bobot 3 , tidak setuju dengan bobot 2, dan sangat tidak setuju dengan bobot 1 .

Menurut Sugiyono (2017), populasi adalah wilayah generalisasi yang terdiri atas obyek/subyek yang mempunyai kualitas dan karakteristik tertentu yang ditetapkan oleh peneliti untuk mempelajari dan kemudian ditarik kesimpulan. Populasi dalam penelitian ini adalah seluruh karyawan Bagian HRD PT. Kreasicipta Aksesdasisido, Jakarta sebanyak 75 orang.

Menurut Sugiyono (2016), sampel adalah sebagian dari jumlah dan karakterisik yang dimiliki oleh populasi tersebut. Teknik pengambilan sampel yang digunakan dalam penelitian ini adalah sampel jenuh. Sampel jenuh adalah teknik penentuan sampel bila semua anggota populasi digunakan sebagai sampel. Hal ini sering dilakukan apabila jumlah populasi relatif kecil. Istilah lain sampel jenuh adalah teknis sensus, dimana semua anggota populasi dijadikan sampel. Jumlah sampel yang digunakan dalam penelitian ini sebanyak 75 orang.

\section{Metode Analisis Data}

\section{Analisis regresi linear sederhana}

Untuk menganalisis pengaruh komunikasi terhadap kepuasan kerja karyawan $\quad$ PT. Kreasicipta Aksesdasisido, Jakarta digunakan analisis regresi linear sederhana yaitu sebagai berikut:

$\mathrm{Y}=\alpha_{1}+\beta_{1} \mathrm{X}_{1}$

Untuk menganalisis pengaruh lingkungan kerja terhadap kepuasan kerja karyawan PT. Kreasicipta Aksesdasisido, Jakarta digunakan analisis regresi linear sederhana yaitu sebagai berikut: 
$Y=\alpha_{2}+\beta_{2} X_{2}$

Untuk menganalisis pengaruh beban kerja terhadap kepuasan kerja karyawan PT. Kreasicipta Aksesdasisido, Jakarta digunakan analisis regresi linear sederhana yaitu sebagai berikut:

$Y=\alpha_{3}+\beta_{3} X_{3}$

\section{Analisis regresi linear berganda}

Untuk menganalisis pengaruh komunikasi, lingkungan kerja dan beban kerja terhadap kepuasan kerja karyawan PT. Kreasicipta Aksesdasisido, Jakarta digunakan analisis regresi linear berganda, yaitu sebagai berikut:

$$
\begin{aligned}
& \mathrm{Y}=\alpha_{4}+\beta_{1} \mathrm{X}_{1}+\beta_{2} \mathrm{X}_{2}+\beta_{3} \mathrm{X}_{3} \\
& \text { dimana } \\
& \mathrm{Y}=\text { Kepuasan kerja } \\
& \mathrm{X}_{1}=\text { Komunikasi } \\
& \mathrm{X}_{2}=\text { Lingkungan kerja } \\
& \mathrm{X}_{3}=\text { Beban kerja } \\
& \mathrm{a}_{\mathrm{i}}=\text { Konstanta }(\mathrm{i}=1,2,3,4) \\
& \mathrm{b}_{\mathrm{i}}=\text { Koeisinen Regresi }(\mathrm{i}=1,2,3)
\end{aligned}
$$

\section{HASIL DAN PEMBAHASAN}

\section{Hasil Penelitian}

\section{Hasil pengujian validitas dan reliabilitas}

Berdasarkan hasil uji validitas dan uji reliabilitas dari variabel yang diteliti, yaitu komunikasi, lingkungan kerja, beban kerja, dan kepuasan kerja menunjukkan bahwa setiap butir pertanyaan yang diajukan kepada responden dinyatakan valid dan reliabel. Hal ini berarti bahwa responden telah memahami setiap pertanyaan yang diajukan dan responden konsisten pada butir pertanyaan yang ditentukan.

\section{Hasil pengujian hipotesis}

Tabel-1: Hasil Pengujian Kausalitas Variabel Penelitian dan Uji Hipotesis

\begin{tabular}{lcccc}
\hline \multirow{2}{*}{$\begin{array}{c}\text { Variabel } \\
\text { Independen }\end{array}$} & \multicolumn{4}{c}{ Koefisien Regresi } \\
\cline { 2 - 5 } & Hipotesis-1 & Hipotesis-2 & Hipotesis-3 & Hipotesis-4 \\
\hline \multirow{2}{*}{ Konstanta } & 18,759 & 17,179 & 29,366 & 5,392 \\
& $(0,000)$ & $(0,000)$ & $(0,000)$ & $(0,257)$ \\
Komunikasi & 0.431 & - & - & 0,268 \\
& $(0,000)$ & - & & $(0,098)$
\end{tabular}




\begin{tabular}{lcccc} 
Lingkungan Kerja & - & 0,485 & & 0,325 \\
& & $(0,000)$ & - & $(0,035)$ \\
Beban Kerja & - & - & 0,351 & 0,457 \\
& & & $(0,080)$ & $(0,000)$ \\
F-hitung & - & - & - & 14,139 \\
$\mathrm{R}^{2}$ & 0,167 & 0,225 & 0,091 & $0,000)$ \\
\hline
\end{tabular}

Keterangan: p-value $<0,10$

Hasil penelitian menunjukkan bahwa estimasi koefisien regresi secara parsial lingkungan kerja terhadap kepuasan kerja sebesar 0,485 lebih besar jika dibandingkan dengan estimasi koefisien regresi komunikasi dan beban kerja terhadap kepuasan kerja, yaitu masing-masing sebesar 0.431 dan 0,351. Selanjutnya, estimasi koefisien regresi secara bersama-sama beban kerja terhadap kepuasan kerja, yaitu sebesar 0,457 lebih besar jika dibandingkan dengan estimasi koefisien regresi komunikasi dan lingkungan kerja terhadap kepuasan kerja, yaitu masing-masing sebesar 0,268 dan 0,325. Hasil penelitian menunjukkan bahwa secara parsial komunikasi, lingkungan kerja, dan beban kerja berpengaruh terhadap kepuasan kerja, sedangkan secara bersama-sama komunikasi, lingkungan kerja dan beban kerja berpengaruh terhadap kepuasan kerja.

\section{Hipotesis pertama}

Koefisien determinasi $\left(\mathrm{R}^{2}\right)$ sebesar 0,167 , artinya komunikasi memberikan konstribusi kepada kepuasan kerja sebesar 16,7\%, sedangkan sisanya sebesar 83,3\% disumbangkan oleh faktor-faktor lain, seperti lingkungan kerja, beban kerja dan berbagai faktor lain. Komunikasi berpengaruh positif dan signifikan pada tingkat nyata $99 \%$ terhadap kepuasan kerja, sesuai dengan hipotesis. Dengan demikian, hipotesis pertama teruji dan hasil penelitian membuktikkan bahwa terdapat hubungan kausalitas antara komunikasi dengan kepuasan kerja. Koefisien regresi komunikasi bertanda positip, artinya jika komunikasi semakin baik, maka kepuasan kerja diduga akan meningkat atau sebaliknya.

\section{Hipotesis kedua}

Koefisien determinasi $\left(\mathrm{R}^{2}\right)$ sebesar 0,225, artinya lingkungan kerja memberikan konstribusi kepada kepuasan kerja sebesar 22,5\%, sedangkan sisanya sebesar $77,5 \%$ disumbangkan oleh faktor-faktor lain, seperti komunikasi, beban kerja dan berbagai faktor lain. Lingkungan kerja berpengaruh positif dan signifikan pada tingkat nyata $99 \%$ terhadap kepuasan kerja, sesuai dengan hipotesis. Dengan demikian, hipotesis kedua teruji dan hasil penelitian membuktikkan bahwa terdapat hubungan kausalitas antara lingkungan kerja dengan kepuasan kerja. Koefisien regresi lingkungan kerja bertanda positip, artinya jika lingkungan kerja semakin membaik, maka kepuasan kerja diduga akan meningkat atau sebaliknya.

\section{Hipotesis ketiga}

Koefisien determinasi $\left(\mathrm{R}^{2}\right)$ sebesar 0,091, artinya beban kerja memberikan konstribusi kepada kepuasan kerja sebesar 9,1\%, sedangkan sisanya sebesar 90,9\% disumbangkan oleh faktor-faktor lain, seperti komunikasi, lingkungan kerja dan berbagai faktor lain. Beban kerja berpengaruh positif dan signifikan pada tingkat nyata 90\% terhadap kepuasan kerja, sesuai dengan hipotesis. Dengan demikian, hipotesis ketiga teruji dan hasil penelitian 
membuktikkan bahwa terdapat hubungan kausalitas antara beban kerja dengan kepuasan kerja. Koefisien regresi beban kerja bertanda positip, artinya jika beban kerja membaik, maka kepuasan kerja diduga akan meningkat atau sebaliknya.

\section{Hipotesis keempat}

Nilai F-hitung sebesar 14,139, artinya secara bersama-sama, komunikasi, lingkungan kerja, dan beban kerja berpengaruh signifikan pada tingkat nyata 99\% terhadap kepuasan kerja. Koefisien determinasi $\left(\mathrm{R}^{2}\right)$ sebesar 0,374 , yang artinya komunikasi, lingkungan kerja, dan beban kerja secara bersama-sama memberikan kontribusi kepada kepuasan kerja sebesar $37,4 \%$, sedangkan sisanya sebesar $62,6 \%$ disumbangkan oleh faktor lain, seperti motivasi kerja, kompensasi, kompetensi, dan berbagai faktor lain.

Koefisien regresi komunikasi, lingkungan kerja, dan beban kerja berpengaruh positif dan signifikan terhadap kepuasan kerja, sesuai dengan hipotesis. Dengan demikian, hipotesis keempat teruji dan hasil penelitian membuktikkan bahwa terdapat hubungan kausalitas antara komunikasi, lingkungan kerja, dan beban kerja dengan kepuasan kerja.

Komunikasi berpengaruh positif dan signifikan terhadap kepuasan kerja karyawan pada tingkat nyata 90\%. Koefisien regresi komunikasi bertanda positif, artinya jika komunikasi dilakukan semakin membaik, maka kepuasan kerja karyawan diduga akan meningkat atau sebaliknya dengan asumsi lingkungan kerja dan beban kerja tidak berubah.

Lingkungan kerja berpengaruh positif dan signifikan pada tingkat nyata 95\% terhadap kepuasan kerja karyawan. Koefisien regresi lingkungan kerja bertanda positif, artinya jika lingkungan kerja dilakukan semakin membaik, maka kepuasan kerja karyawan diduga akan meningkat atau sebaliknya dengan asumsi komunikasi dan beban kerja tidak berubah.

Beban kerja berpengaruh positif dan signifikan pada tingkat nyata 99\% terhadap kepuasan kerja karyawan. Koefisien regresi beban kerja bertanda positif, artinya jika beban kerja semakin membaik, maka kepuasan kerja karyawan diduga akan meningkat atau sebaliknya dengan asumsi komunikasi dan lingkungan kerja tidak berubah.

\section{Pembahasan}

\section{Pengaruh komunikasi terhadap kepuasan kerja}

Perbaikan komunikasi mendukung peningkatan kepuasan kerja karyawan PT. Kreasicipta Aksesdasisido, Jakarta, hal ini dikarenakan komunikasi antara atasan dan bawahan dilakukan dengan penuh komunikatif, komunikasi antara sesama karyawan mudah untuk dimengerti, dan komunikasi antara divisi sudah terjalin dengan baik. Hasil penelitian ini mendukung hasil penelitian yang dilakukan oleh Wulandari, et al (2018), Yunsepa (2018), dan Putra dan Adnyani (2019), yang telah membuktikan bahwa perbaikan komunikasi dapat mendorong peningkatan kepuasan kerja karyawan.

\section{Pengaruh lingkungan kerja terhadap kepuasan kerja}

Perbaikan lingkungan kerja mendukung peningkatan kepuasan kerja karyawan PT. Kreasicipta Aksesdasisido, Jakarta, hal ini dikarenakan lingkungan kerja yang kondusif sangat berpengaruh pada produktivitas kerja karyawan, atasan memberikan apresiasi terhadap prestasi kerja karyawan, dan kerjasama antar karyawan berjalan dengan baik. Hasil penelitian ini sesuai dan memperkuat hasil penelitian terdahulu yang dilakukan oleh Wuwung, et al (2017), Aolio dan Lao (2018), Yunsepa (2018), Prassetiawan (2018), Dino (2019), Putra dan Adnyani (2019), Fachrezi (2020), dan Novtia, et al (2020) yang telah 
membuktikan bahwa perbaikan lingkungan kerja dapat mendorong peningkatan kepuasan kerja karyawan.

\section{Pengaruh beban kerja terhadap kepuasan kerja}

Perbaikan beban kerja mendukung peningkatan kepuasan kerja karyawan PT. Kreasicipta Aksesdasisido, Jakarta, hal ini dikarenakan karyawan dapat meyelesaikan pekerjaan sesuai dengan waktu yang ditentukan, dan karyawan bekerja sesuai target kerja yang telah ditetapkan. Hasil penelitian ini mendukung hasil penelitian yang dilakukan oleh Novtia (2020) yang telah membuktikan bahwa perbaikan beban kerja dapat mendorong peningkatan kepuasan kerja karyawan.

\section{Pengaruh komunikasi, lingkungan kerja, dan beban kerja terhadap kepuasan kerja}

Perbaikan komunikasi, lingkungan kerja, dan beban kerja mendukung peningkatan kepuasan kerja karyawan PT. Kreasicipta Aksesdasisido, Jakarta. Hal ini dikarenakan komunikasi antara atasan dan bawahan dilakukan dengan penuh komunikatif, komunikasi antara sesama karyawan mudah untuk dimengerti, komunikasi antara divisi sudah terjalin dengan baik, lingkungan kerja yang kondusif sangat berpengaruh pada produktivitas kerja karyawan, atasan memberikan apresiasi terhadap prestasi kerja karyawan, kerjasama antar karyawan berjalan dengan baik, karyawan dapat meyelesaikan pekerjaan sesuai dengan waktu yang ditentukan, dan karyawan bekerja sesuai target yang telah ditetapkan. Hasil penelitian ini mendukung hasil penelitian yang dilakukan oleh Putra dan Adnyani (2019) yang telah membuktikan bahwa perbaikan komunikasi, lingkungan kerja dan beban kerja secara bersama-sama dapat mendorong peningkatan kepuasan kerja karyawan.

\section{KESIMPULAN DAN SARAN}

\section{Kesimpulan}

1. Perbaikan komunikasi dapat mendorong peningkatan kepuasan kerja karyawan PT. Kreasicipta Aksesdasisido, Jakarta.

2. Perbaikan lingkungan kerja dapat mendorong peningkatan kepuasan kerja karyawan PT. Kreasicipta Aksesdasisido, Jakarta.

3. Perbaikan beban kerja dapat mendorong peningkatan kepuasan kerja karyawan PT. Kreasicipta Aksesdasisido, Jakarta.

4. Perbaikan komunikasi, lingkungan kerja, dan beban kerja dapat mendorong peningkatan kepuasan kerja karyawan PT. Kreasicipta Aksesdasisido, Jakarta.

\section{Saran}

1. Perlu dipertimbangkan agar perbaikan komunikasi melalui komunikasi yang berasal dari atas ke bawah, yaitu perintah, prosedur, teguran dan pujian, dan komunikasi yang berasal dari bawah ke atas, yaitu saran dan laporan pekerjaan dalam mendorong peningkatan kepuasan kerja karyawan PT. Kreasicipta Aksesdasisido, Jakarta secara berkesinambungan.

2. Perlu dipertimbangkan agar perbaikan lingkungan kerja melalui lingkungan fisik, seperti penerangan, suhu udara, suara bising, penggunaan warna, dan keamanan kerja, dan lingkungan non fisik, seperti hubungan kerja antara pimpinan dan bawahan, dan hubungan kerja antara rekan kerja dalam mendorong peningkatan kepuasan kerja karyawan PT. Kreasicipta Aksesdasisido, Jakarta secara berkesinambungan. 
3. Perlu dipertimbangkan agar perbaikan beban kerja melalui kondisi pekerjaan, penggunaan waktu kerja, dan target kerja yang harus dicapai dalam mendorong peningkatan kepuasan kerja karyawan PT. Kreasicipta Aksesdasisido, Jakarta secara berkesinambungan.

4. Bagi penelitian selanjutnya disarankan untuk menempatkan variabel kinerja karyawan sebagai variabel dependen dan kepuasan kerja sebagai variabel yang memediasi hubungan korelasional antara variabel komunikasi dan lingkungan kerja dengan kinerja karyawan.

\section{DAFTAR PUSTAKA}

Ajabar. 2020. Manajemen Sumber Daya Manusia. Yogyakarta: Deepublish.

Aoliso, Lao. 2018. Pengaruh Lingkungan Kerja terhadap Kepuasan Kerja Karyawan pada PT.Taspen (Persero) Kantor Cabang Kupang. BISMAN, Jurnal Bisnis dan Manajemen. Vol.3 No.1, Juni 2018, hal: 9-16.

Diana. 2019. Pengaruh Beban Kerja terhadap Kinerja Karyawan di Housekeeping Departement Pada Hotel Bintan Lagoon Resort. Jurnal Manajemen Tools. Vol.11, No. 2, Desember 2019.

Dino, Vallent Alfan. 2019. Pengaruh Motivasi Kerja dan Lingkungan Kerja Karyawan Pada PT. Jasa Raharja Cabang Jambi. Skripsi Fakultas Ekonomi dan Bisniss Islam Universitas Islam Negeri Sulthan Thana Saifuddin.

Edy, Sutrisno. 2016. Manajemen Sumber Daya Manusia. Kencana Prenada Media Group, Jakarta.

Efendi, Pandi. 2018. Manajemen Sumber Daya Manusia. Pekanbaru. Zanafa Publishing

Fachrezi, Khair. 2020. Pengaruh Komunikasi, Motivasi dan Lingkungan Kerja terhadap Kinerja Karyawan pada PT. Angkasa Pura II (Persero) Kantor Cabang Kualanamu. Jurnal Ilmiah Magister Manajemen. Vol. 3, No.1, Maret 2020, hal:107-119.

Firdaus. 2021. Metode Penelitian Kuantitatif. Riau: DOTPLUS Publisher.

Hamali, Arif Yusuf. 2016. Pemahaman Sumber Daya Manusia. Yogyakarta: CAPS.

Hannani, et al. 2016. Pengaruh Beban Kerja, Kepuasan, dan Fasilitas terhadap Kinerja Perawat di Ruang Perawatan Mawar Lantai Ii Rsu WisataUit Makassar. Jurnal Mirai Management. Vol.1 No.2, Oktober 2016.

Koesomowidjojo, S. R. 2017. Analisis Beban Kerja. Jakarta. Raih Asa Sukses.

Mangkunegara, A. A. Anwar Prabu 2017. Manajemen Sumber Daya Manusia Bandung. Remaja Rosdakarya.

Nabawi, R. 2019. Pengaruh Lingkungan Kerja, Kepuasan Kerja dan Beban Kerja terhadap Kinerja Pegawai. Jurnal Ilmiah Magister Manajemen. Vo.2, No.2, September 2019, hal:170-183.

Ngalimun. 2017. Ilmu Komunikasi (Sebuah Pengantar Praktis). Yogyakarta: Pustaka Baru Press.

Novtia, et al. 2020. Pengaruh Beban Kerja dan Lingkungan Kerja terhadap Kepuasan Kerja Karyawan (Studi Kasus pada Karyawan Koperasi Nusantara Cabang Bengkulu dan Curup). Jurnal Manjemen Modal Insani Dan Bisnis (JMMIB). Vol. 1, No. 2, Desember 2020.

assetiawan, Triyani. 2018. Pengaruh Motivasi, Kompensasi dan Lingkungan Kerja terhadap Kepuasan Kerja Karyawan (Studi Pada Cv Enggal Jaya Semarang). Majalah Ilmiah Solusi. Vol.16, No.4 Oktober 2018. 
Purwanto, Djoko. 2015. Komunikasi Bisnis. Edisi Revisi. Jakarta: Bumi Aksara

Putra dan Adnyani. 2019. Pengaruh Komunikasi, Budaya Organisasi dan Lingkungan Kerja Fisik terhadap Kepuasan Kerja Karyawan Ramada Bintang Bali. E-Jurnal Manajemen. Vol.8, No.4 2019, hal: 2014-2041.

Riniwati, H. (2016). Manajemen Sumber Daya Manusia (Aktifitas Utama dan Pengembangan SDM). Malang. UB Press.

Rivai, Veithzal, et al. 2015. Manajemen Sumber Daya Manusia untuk Perusahaan dari Teori ke Praktik. Depok. PT. Rajagrafindo Persada.

Robbins dan Judge, 2015. Perilaku Organisai. Jakarta. Salemba Empat.

Ruliana, Poppy. 2016. Komunikasi Organisasi: Teori dan Studi Kasus. Jakarta. PT. Raja Grafindo Perkasa.

Sedarmayanti. 2016. Manajemen Sumber Daya Manusia. Bandung. PT. Refika Aditama.

Sinambela, Lijan Poltak. 2018. Manajemen Sumber Daya Manusia: Membangun Tim Kerja yang Solid untuk Meningkatkan Kinerja. Jakarta. PT. Bumi Aksara.

Slamet Riyanto, A. A. 2020. Metode Penelitian Kuantitatif di Bidang Manajemen, Teknik, Pendidikan, dan Eksperimen. Deepublish Publisher.

Sudjana, N. 2016. Penelitian Hasil Proses Belajar Mengajar. Bandung. Rosdikarya.

Sugiyono. 2017. Metode Penelitian Kuantitatif. Bandung. Alfabeta.

Sugiyono. 2016. Metodologi Penelitian Kuantitatif, Kualitatif, dan R\&D. Bandung. Alfabeta

Sutrisno, Edy. 2019. Manajemen Sumber Daya Manusia. Jakarta. Prenadamedia Group.

Syamsudin, Acep dan Hilman, Firmansyah. 2016. Organisasi dan Manajemen Bisnis. Yogyakarta: Ombak.

Wahyuni, Irfani. 2019. Pengaruh Kompensasi dan Beban Kerja terhadap Kepuasan Kerja dalam Meningkatkan Kinerja Karyawan Pt. Kepsindo Indra Utama Padang. Jurnal PSYCHE 165 Fakultas Psikologi. Vol.12, No.1, Januari 2019.

Wulandari, et al. 2018. Pengaruh Komunikasi dan Kompensasi terhadap Kepuasan Kerja Karyawan di PT. Muara Krakatau II Kabupaten Semarang. Pendidikan Administrasi Perkantoran Fakultas Keguruan dan Ilmu Pendidikan, Universitas Sebelas Maret Surakarta.

Wuwung, et al. (2017). Pengaruh Lingkungan Kerja dan Motivasi Kerja terhadap Kepuasan Kerja Karyawan Cinemax Lippo Plaza Manado. Jurnal EMBA. Vol.5 No.2, Juni 2017.

Yunsepa. (2018). Pengaruh Lingkungan Kerja, Komunikasi, Kompetensi dan Kompensasi terhadap Kepuasan Kerja Karyawan Pabrik Sogm Pada Pt Perkebunan Minanga Ogan Region Sumsel-Lampung. Jurnal Ecoment Global. Vol.3 No.1, Februari 2018.

Yusuf, Burhanuddin. 2015. Manajemen Sumber Daya Manusia di Lembaga Keuangan Syariah. Jakarta. PT. Raja Grafindo Persad 
